American Journal of Applied Sciences 9 (9): 1518-1526, 2012

ISSN 1546-9239

(C) 2012 Science Publication

\title{
The Relationship Between Job Satisfaction and Turnover Intention
}

\author{
${ }^{1}$ Ahmad Faisal Mahdi, ${ }^{2}$ Mohamad Zaid Mohd Zin, \\ ${ }^{3}$ Mohd Roslan Mohd Nor, ${ }^{4}$ Ahamad Asmadi Sakat and ${ }^{1}$ Abang Sulaiman Abang Naim \\ ${ }^{1}$ Faculty of Business Management, \\ Universiti Technology Mara, 94300 Samarahan, Sarawak, Malaysia \\ ${ }^{2}$ Centre for Islamic Thought and Understanding, \\ University Technology Mara, 94300 Samarahan, Sarawak, Malaysia \\ ${ }^{3}$ Department of Islamic History and Civilization, \\ Academy of Islamic Studies, University of Malaya, 50603 Kuala Lumpur, Malaysia \\ ${ }^{4}$ Department of Al Quran and Al Sunnah Studies, \\ Faculty of Islamic Studies, Universiti Kebangsaan Malaysia, 43600 Bangi, Selangor, Malaysia
}

\begin{abstract}
Problem statement: The objective of this study were to determine the effect of job satisfaction on turnover intentions among the employees in XYZ Sdn. Bhd, Malaysia. Approach: A total of 32 set of complete questionnaires gathered from executives and non-executives of a local printing company were involved in the study and 32 completed the questionnaires. Using structured questionnaires in a controlled environment, the results manage to extract both intrinsic and extrinsic job satisfaction that influences the turnover intention. Results: The statistical results obtained in this study showed that both forms of job satisfaction (intrinsic and extrinsic satisfaction) have inverse relationship on employees' turnover intentions. Conclusion: Eventhough Instrinsic Job Satisfaction have stronger influence on Turnover Intention. Existence of Extrinstic Job Satisfaction also must be consider in measuring the intention.
\end{abstract}

Key words: Intrinsic, Extrinsic, Job Satisfaction and Turnover Intention

\section{INTRODUCTION}

In an organization, what makes an employee leave or intend to leave are always become the big question for any company. Several studies have examined job satisfaction as an antecedent of turnover intentions (for instance, Mobley et al., 1979; Price and Mueller, 1981; Shore and Martin, 1989; Hellman, 1997; Ghiselli et al., 2001; McBey and Karakowsky, 2001). These studies, however, were conducted in the United States and Canada. The industries investigated were wide ranging covering hospitals, military and food-service companies. Although job satisfaction has been found to be a rather consistent predictor of turnover intentions, the strength of the satisfaction-intention to leave relationship varies according to each setting. In addition, little work has been undertaken using professional subjects within the South East Asian context (for example, Aryee and Wyatt, 1991; Chan and Morrison, 2000). The objective of this study is to examine the effects of intrinsic and extrinsic job satisfaction on turnover intentions of employees.

Job satisfaction may be defined as a pleasurable or positive emotional state resulting from the appraisal of one's job or job experiences (Dunnette and Locke, 1976). This positive feeling results from the perception of one's job as fulfilling or allowing the fulfillment of one's important job values, provided these values are compatible with one's needs (Dunnette and Locke, 1976). Given that values refer to what one desires or seeks to attain (Locke, 1969), job satisfaction can be considered as reflecting a person's value judgment regarding workrelated rewards. Locke and Henne (1986) define job satisfaction as the pleasurable emotional state resulting from the achievement of one's job values in the work situation.

Work rewards reflect the intrinsic and extrinsic benefits that workers receive from their jobs (Kalleberg,

Corresponding Author: Ahmad Faisal Mahdi, Faculty of Business Management, Universiti Technology Mara, 94300 Samarahan, Sarawak. Malaysia 
1977). Two important groups of work rewards that have been identified include task and organizational rewards. Task rewards refer to those intrinsic rewards directly associated with doing the job (Katz and Maanan, 1977; Mottaz, 1988). They include such factors as interesting and challenging work, self-direction and responsibility, variety and opportunities to use one's skills and abilities. Organizational rewards, on the other hand, refer to the extrinsic rewards provided by the organization for the purpose of facilitating or motivating task performance and maintaining membership (Katz and Maanan, 1977; Mottaz, 1988). They represent tangible rewards that are visible to others and include such factors like pay, promotions, fringe benefits, security and comfortable working conditions.

According to Loscocco (1989), every working person has a certain order of priorities with regard to what he or she seeks from work. It is generally assumed that individual's value economic (extrinsic) as well as intrinsic job reward. Some workers may strongly emphasize both types of rewards, some may place little value on either and others may emphasize one type and deemphasize the other. Nevertheless, both forms of rewards contribute to job satisfaction (O'Reilly and Caldwell, 1980). A job that entails high pay, high security, greater promotional opportunities, interesting work and fair and friendly supervision, all of which is judged as a way to achieve work and non-work goals, should lead to positive feelings of well-being.

Meanwhile, a relevant research by Spector (1997) and Hirschfeld (2000) indicate that the different aspects of job satisfaction could be split according to Herzberg's two dimensions. The intrinsic satisfaction refers to job tasks and job content such as variety, autonomy, skill utilization, self-fulfillment and selfgrowth. And at the same time, Buitendach and Witte (2005) state that extrinsic motivation refers to other factors such as pays, co-workers and work conditions.

Intentions are, according to researchers such as Fishbein and Ajzen (1975) and Igbaria et al. (1995), the most immediate determinants of actual behavior. The validity of studying intentions in the workplace can also be drawn from Sager (1991) longitudinal study of salespeople, in which intention to quit was found to differentiate effectively between the leavers and worker that stays. However, while it is reasonable to argue that intentions are an accurate indicator of subsequent behavior, researchers still do not know what determines such intentions.

Intention to turnover refers to an individual's perceived probability of staying or leaving an employing organization (Cotton and Tuttle, 1986). Tett and Meyer (1993), on the other hand, referred to turnover intentions as a conscious and deliberate willfulness to leave the organization. Barak et al. (2001) in their review of antecedents to turnover argued that many studies use intent to leave rather than actual turnover as the outcome variable due to two main reasons. First, there is evidence to indicate that workers typically make a conscious decision to do so before actually leaving their jobs. This relationship is supported by the attitude-behavior theory (Fishbein and Ajzen, 1975), which holds that one's intention to perform a specific behavior is the immediate determinant of that behavior.

Second, it is more practical to ask employees of their intention to quit in a cross-sectional study than actually tracking them down via a longitudinal research to see if they have left. In addition, actual turnover may be more difficult to predict, as there may be other factors such as employment alternatives that affect a person's turnover behavior. According to Muchinsky and Morrow (1980), an unfavorable economy may reduce a person's flexibility to move elsewhere leading to lower correlations between intent to leave and actual turnover whilst the job satisfaction-intention to leave relationship tend to be stronger when greater economic choice existed.

Job satisfaction is one the factors that contribute to people's intention to quit their jobs (Moore, 2002); however, it is important both manager's and the individual's perspective to understand the factors that mediate the relationship between job stress and turnover intention.

Although a worker's "intention to leave" is considered a sign of quitting, there are no consistent findings that regard to its value as a predictor of the actual turnover to the workers. Supported by Parasuraman (1982) in his studies found a positive significant of relationship.

Numerous researchers (Bluedorn, 1982; Kalliath and Beck, 2001; Kramer et al., 1995; Price and Mueller, 1981; Saks, 1996) have attempted to answer the question of what determines people's turnover intention by investigating possible previous circumstances that lead to employees' intentions to quit. So far, there has been little consistency in the findings, which is partly due to the diversity of constructs included by the researchers and the lack of consistency in their measurements but also relates to the heterogeneity of populations sampled.

Social support has been shown to play an important role in mitigating intention to quit, although not all findings have been in agreement. For example, Moore (2002) found that social support from supervisors reduced the level of nurses' burnout and indirectly, through reduced levels of burnout, reduced nurses' 
intention to quit. A similar result by Kalliath and Beck (2001) when they tested the impact of social support on two components of burnout, namely depersonalization and emotional exhaustion and found that supervisory support reduced not only those symptoms of burnout but also directly and indirectly nurses' turnover intention.

On the other hand, Munn et al. (1996), in a study of American child life specialists, found lack of supervisor support was the best predictor of job dissatisfaction and intention to leave a job, while Hatton and Emerson (1998) found that actual staff turnover was predicted in part by low levels of support from superiors. However, other studies Rahim and Psenicka (1996) have failed to find a moderating effect for social support in the relationship between job stressors and turnover intention.

Other researchers such as (Kelly and Cross, 1985) have found that rather than supervisors' support, it is the support gained from talking with peers, family and friends that is frequently cited as a source of stress reduction. Consistent with these findings, Freddolino and Heaney (1992) found that peer social support was associated with higher job satisfaction among direct care staff and home managers for intellectually disabled clients, while turnover intention was associated with the presence of social undermining by co-workers and provider agencies. However, the bulk of evidence suggests that it is situation-specific support, that is, work-supervisor/home-family, Tinker and Moore (2001) that is most effective.

Job satisfaction has been defined as a pleasurable emotional state resulting from the appraisal of one's job or job experience as stated by Dunnette and Locke (1976). This positive feeling results from the perception of one's job as fulfilling or allowing the fulfillment of one's important job values, provided these values are compatible with one's needs, Dunnette and Locke (1976). Given that values refer to what one desires or seeks to attain, Dunnette and Locke (1976), job satisfaction can be considered as reflecting a person's value judgment regarding work-related rewards. Locke and Henne (1986) defined job satisfaction as the pleasurable emotional state resulting from the achievement of one's job values in the work situation. According to Williams and Hazer (1986), job satisfaction is an individual's affective response to specific aspects of one's job.

Similarly, Mottaz (1988) regard job satisfaction as an effective response resulting from an evaluation of the work situation. Glick (1992) view job satisfaction as an effective response by individuals resulting from an appraisal of their work roles in the job that they presently hold. According to Robbins (2003), job satisfaction refers to an individual's general attitude toward his or her job. In sum, the job satisfaction construct can be considered as an effective response by an employee concerning his or her particular job and results from the employee's comparison of actual rewards or outcomes with those that are expected, needed, valued, wanted, or perceived to be fair (Spector, 1997).

Work rewards reflect the intrinsic and extrinsic benefits that workers receive from their jobs (Kalleberg, 1977). Two important groups of work rewards that have been identified include task and organizational rewards. Task rewards refer to those intrinsic rewards directly associated with doing the job (Katz and Maanan, 1977; Mottaz, 1988). They include such factors as interesting and challenging work, self-direction, responsibility, variety and opportunities to use one's skills and abilities. Organizational rewards, on the other hand, refer to the extrinsic rewards provided by the organization for the purpose of facilitating or motivating task performance and maintaining membership (Katz and Maanan, 1977; Mottaz, 1988). They represent tangible rewards that are visible to others and include such factors like pay, promotions, fringe benefits, security and comfortable working conditions.

Job satisfaction has been repeatedly identified as the main reason why employees leave their jobs (Barak et al., 2001). Many studies (for example, Mobley et al., 1978; Price and Mueller, 1981; Shore and Martin, 1989; Aryee and Wyatt, 1991; Hellman, 1997; Chan and Morrison, 2000; Ghiselli et al., 2001; McBey and Karakowsky, 2001) have reported a significant negative relationship between job satisfaction and intention to leave the organization.

Tan (1998) assess job satisfaction and turnover intention of employees in the travel agencies in Malaysia. Seventy-two items of Job Descriptive Index (JDI) were used to determine the job satisfaction level. Tan also found that job satisfaction was significantly related with intention-to-leave.

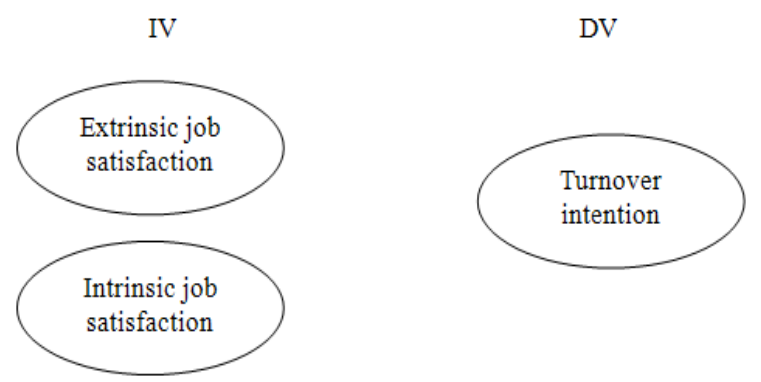

Fig. 1: Relationship between job satisfaction and turnover intention Source Nasurdin et al. (2003) 
Saal and Knight (1995) report that JDI, Minnesota Satisfaction Questionnaire and face scale were the most popular job satisfaction measures. However, JDI is found to be the most frequently used as measurement of job satisfaction compared to the other. Vroom (1994) called it as the measure without doubt and the most carefully constructed measure of job satisfaction.

Referring to Fig. 1, the framework were adapted and modified from Nasurdin et al. (2003) previous research, which the independent variables consists elements like working condition, co-worker and supervisor under extrinsic job satisfaction and element of work value in intrinsic job satisfaction.

\section{MATERIALS AND METHODS}

Subjects were the executives and non-executives of a local printing company employee. 36 structured questionnaires were distributed through a control environment and 32 return back complete. That yields $89 \%$ of the respondents' size.

Random sampling technique was used to distribute set of questionnaire which were adopted and adapted from Smith et al. (1969) and Nasurdin et al. (2003) in order to determine the employees' opinions regarding turnover intention in the company. The questionnaires were divided into four main parts. The first and the second part measured the respondent's working condition, supervision, co-workers, as well work value in the second part. A five-point Likert scale was used to indicate the respondent's answers (1-Strongly Disagree; 2-Disagree; 3-Neither Agree nor Disagree; 4-Agree; 5Strongly Agree). Supported through Thomas and Tymon (1994) measurement regarding satisfaction and turnover intention as well. The third part were used as an indicator of measurement to measures the respondents intention to leave which use multiplechoice that suits the best decision they will make representing their intention in the organization. The fourth part of the questionnaire was regarded the respondent's demographic background, which include gender, age, marital status, department, position (executive/non executive) and education.

Using the Statistical Package for Social Science version 12.0 for Windows, we process the data that collected from the respondents and several tests were carried out to test the variables. Cronbach's Alpha values were extracted from the reliability test on the variables (intrinsic, extrinsic job satisfaction and turnover intention). In addition, correlation analyses on the three variables were also obtained to identify the most relevant and significant relationship among the variables.

\section{RESULTS}

The statistical analyses were computed using SPSS version 12.0 for Windows to extract the data and results. There are several results which are displayed below from the study.

Table 1 below explains the background of the respondents. $75 \%$ respondents were percent female. In addition, an equal 50 percentage for age group of the respondents which were 18-24 years and 25-34 years. And then, $87.5 \%$ of the respondents' were single. Job tenure shows $37.5 \%$ group each work less than a year and another 1 year to 2 years plus. $62.5 \%$ respondents were non executives. Finally, the employees were divided into 3 group; first degree $37.5 \%$, diploma 37.5 and STPM 25\%.

According to the Table 2, the Cronbach's Alpha coefficient for the Intrinsic Satisfaction (Work Value) scale is 0.883 . There are total of 20 items in this scale and no item being removed as since the reliability of the measurement indicates that the independent variable is in 'very good' range.

According to the Table 3, the Cronbach's Alpha coefficient for the Extrinsic Satisfaction (Working Condition) scale is 0.78 . There are total of 18 items in this scale, whereby 9 of them (satisfying, respected, pleasant environment, useful career, tiresome and burden, challenging, frustrating, endless and give sense of accomplishment) have been omitted to increase the reliability of the measurement. Referring to the rules of thumb, the independent variable indicates that the reliability test is in 'good' range.

Table 1: Respondents background

\begin{tabular}{llrr}
\hline & & Frequency & Percent \\
\hline Gender & Male & 8 & \\
& Female & 24 & 25.0 \\
Age & Total & 32 & 75.0 \\
& & & 100.0 \\
& $18-24$ & 16 & 50.0 \\
Status & $25-34$ & 16 & 50.0 \\
& Total & 32 & 100.0 \\
& Single & 28 & 87.5 \\
Job Tenure & Married & 4 & 12.5 \\
& Total & 32 & 100.0 \\
& & & \\
& $>1$ Year & 12 & 37.5 \\
Position & 1 to $<$ Years & 12 & 37.5 \\
& Above 3 Years & 8 & 25.0 \\
& Total & 32 & 100.0 \\
& & & 37.5 \\
Education & Executive & 12 & 62.5 \\
& Non-executive & 20 & 100.0 \\
& Total & 32 & 25.0 \\
& & & 37.5 \\
& SPM/STPM & 8 & 37.5 \\
& Diploma & 12 & 100.0 \\
\hline & First Degree & 12 &
\end{tabular}


Am. J. Applied Sci., 9 (9): 1518-1526, 2012

Table 4 shows the Cronbach's Alpha coefficient for Extrinsic Satisfaction (Supervisor) scale is 0.829 . There are total of 18 items in this scale, whereby 4 items (hard to please, bad, lazy and around when needed) have been omitted to increase the reliability of the measurement. Referring to the rules of thumb, the independent variable indicates that the reliability test is in 'very good' range.
Table 5 indicates the Cronbach's Alpha coefficient for the Extrinsic Satisfaction (Co-Worker) scale is 0.850 . There are total of 18 items in this scale, whereby 4 items (boring, slow, stupid and low interest) have been omitted to increase the reliability of the measurement. Referring to the rules of thumb, the independent variable indicates that the reliability test is in 'very good' range.

Table 2: Reliability test for intrinsic satisfaction (Work Value)

\begin{tabular}{|c|c|c|c|c|}
\hline Item- total statistics & $\begin{array}{l}\text { Scale mean } \\
\text { if Item } \\
\text { deleted }\end{array}$ & $\begin{array}{l}\text { Scale variance } \\
\text { if Item } \\
\text { deleted }\end{array}$ & $\begin{array}{l}\text { Corrected } \\
\text { item-total } \\
\text { correlation }\end{array}$ & $\begin{array}{l}\text { Cronbach's } \\
\text { alpha If } \\
\text { item deleted }\end{array}$ \\
\hline Able to keep busy all the time & 64.6250 & 62.952 & 0.401 & 0.880 \\
\hline Given the chance to work alone on the job & 64.7500 & 64.968 & 0.164 & 0.885 \\
\hline Given the chance to do different things from time to time & 64.3750 & 53.661 & 0.933 & 0.860 \\
\hline Given the chance to be "somebody" in the community & 64.3750 & 57.790 & 0.747 & 0.869 \\
\hline Like the way my boss handles his/her workers & 64.6250 & 62.435 & 0.227 & 0.887 \\
\hline Like the competence of my supervisor in making decisions. & 64.7500 & 61.871 & 0.615 & 0.876 \\
\hline Being able to do things that don't go against my conscience & 64.7500 & 61.871 & 0.615 & 0.876 \\
\hline Like the way my job provides for steady employment & 64.3750 & 57.790 & 0.747 & 0.869 \\
\hline Given the chance to tell peoples what to do & 64.6250 & 58.823 & 0.645 & 0.872 \\
\hline Given the chance to do things for other people & 64.6250 & 53.145 & 0.827 & 0.863 \\
\hline Given the chance to do something that makes use of my abilities & 64.3750 & 57.790 & 0.747 & 0.869 \\
\hline Like the way company policies are put into practice & 64.5000 & 58.581 & 0.517 & 0.877 \\
\hline Happy with my pay and the amount of work I do & 65.3750 & 63.468 & 0.209 & 0.886 \\
\hline Given the chance for advancement on this job & 64.8750 & 59.210 & 0.531 & 0.876 \\
\hline Given the freedom to use my own judgment & 64.5000 & 60.903 & 0.437 & 0.879 \\
\hline Given the chance to try my own methods of doing the job & 64.7500 & 66.774 & -.093 & 0.906 \\
\hline Like the working conditions & 64.6250 & 65.790 & 0.036 & 0.888 \\
\hline Like the way my co-workers get along with each other & 64.5000 & 62.710 & 0.272 & 0.884 \\
\hline Like the praise I get for doing a good job & 64.2500 & 56.710 & 0.905 & 0.865 \\
\hline Like the feeling of accomplishment I get from the job & 64.3750 & 57.274 & 0.799 & 0.867 \\
\hline
\end{tabular}

Like the feeling of accomplishment I get from the job

64.3750

0.867

Table 3: Reliability test for extrinsic satisfaction (Working Condition)

\begin{tabular}{|c|c|c|c|c|c|}
\hline $\begin{array}{l}\text { Item- total } \\
\text { statistics }\end{array}$ & $\begin{array}{l}\text { Scale mean if } \\
\text { Item deleted }\end{array}$ & $\begin{array}{l}\text { Scale variance } \\
\text { if Item deleted }\end{array}$ & \multicolumn{2}{|c|}{$\begin{array}{l}\text { corrected item- } \\
\text { total correlation }\end{array}$} & $\begin{array}{l}\text { Cronbach's alpha } \\
\text { If item deleted }\end{array}$ \\
\hline Fascinating & 24.5000 & 23.742 & \multicolumn{2}{|c|}{0.188} & 0.787 \\
\hline Same routine & 25.0000 & 16.258 & \multicolumn{2}{|c|}{0.756} & 0.705 \\
\hline Boring & 25.2500 & 19.806 & \multirow{2}{*}{\multicolumn{2}{|c|}{$\begin{array}{l}0.349 \\
0.387\end{array}$}} & 0.784 \\
\hline Good incentives & 25.0000 & 21.419 & & & 0.769 \\
\hline Creative & 25.0000 & 21.677 & \multicolumn{2}{|c|}{$\begin{array}{l}0.387 \\
0.349\end{array}$} & 0.774 \\
\hline Hot environment & 25.8750 & 18.177 & \multicolumn{2}{|c|}{0.685} & 0.724 \\
\hline Healthful & 24.3750 & 20.629 & \multicolumn{2}{|c|}{0.464} & 0.760 \\
\hline On your feet & 24.7500 & 21.871 & \multicolumn{2}{|c|}{0.380} & 0.770 \\
\hline Simple & 25.2500 & 18.258 & \multicolumn{2}{|c|}{0.600} & 0.737 \\
\hline \multicolumn{2}{|l|}{ Item- total statistics } & $\begin{array}{l}\text { Scale mean } \\
\text { if Item } \\
\text { deleted }\end{array}$ & $\begin{array}{l}\text { Scale variance } \\
\text { if Item } \\
\text { deleted }\end{array}$ & $\begin{array}{l}\text { corrected } \\
\text { item-total } \\
\text { correlation }\end{array}$ & $\begin{array}{l}\text { Cronbach's } \\
\text { alpha If } \\
\text { item deleted }\end{array}$ \\
\hline \multicolumn{2}{|l|}{ Always ask my advice } & 42.0000 & 32.000 & 0.635 & 0.807 \\
\hline \multicolumn{2}{|l|}{ Impolite } & 42.8750 & 34.694 & 0.166 & 0.844 \\
\hline \multicolumn{2}{|l|}{ Praises good work } & 41.7500 & 28.839 & 0.898 & 0.784 \\
\hline \multicolumn{2}{|l|}{ Tactful } & 42.0000 & 35.097 & 0.386 & 0.823 \\
\hline \multicolumn{2}{|c|}{ Influential in changing my behavior } & 42.3750 & 33.532 & 0.383 & 0.823 \\
\hline \multicolumn{2}{|c|}{ Up to date in giving information about the job } & 41.8750 & 31.081 & 0.497 & 0.816 \\
\hline \multicolumn{2}{|c|}{ Short of supervision } & 42.6250 & 31.984 & 0.565 & 0.811 \\
\hline \multicolumn{2}{|l|}{ Quick tempered } & 42.7500 & 32.968 & 0.413 & 0.822 \\
\hline \multicolumn{2}{|l|}{ Tells me where I stand } & 41.8750 & 32.113 & 0.632 & 0.807 \\
\hline \multicolumn{2}{|l|}{ Annoying } & 42.8750 & 38.048 & -.100 & 0.851 \\
\hline & 43.2500 & 33.226 & 0.516 & 0.815 \\
\hline \multicolumn{2}{|l|}{ Knows the job well } & 41.5000 & 30.452 & 0.664 & 0.802 \\
\hline \multicolumn{2}{|l|}{ Intelligent } & 41.7500 & 33.484 & 0.481 & 0.817 \\
\hline \multicolumn{2}{|l|}{ Self empowered } & 42.0000 & 33.290 & 0.467 & 0.818 \\
\hline
\end{tabular}


Am. J. Applied Sci., 9 (9): 1518-1526, 2012

Table 5: Reliability test for extrinsic satisfaction (Co-Worker)

\begin{tabular}{lllcc}
\hline Item- total & $\begin{array}{l}\text { Scale mean } \\
\text { if Item } \\
\text { statistics }\end{array}$ & $\begin{array}{l}\text { variance } \\
\text { if Item } \\
\text { deleted }\end{array}$ & $\begin{array}{l}\text { Scale } \\
\text { corrected } \\
\text { item-total } \\
\text { correlation }\end{array}$ & $\begin{array}{l}\text { Cronbach's } \\
\text { alpha If } \\
\text { item deleted }\end{array}$ \\
\hline Encouraging & 39.3750 & 41.790 & 0.356 & 0.853 \\
Ambitious & 39.7500 & 42.258 & 0.635 & 0.834 \\
Responsible & 39.3750 & 36.113 & 0.713 & 0.824 \\
Fast & 39.1250 & 43.726 & 0.517 & 0.841 \\
Intelligent & 39.2500 & 37.355 & 0.826 & 0.817 \\
Easy to & & & & \\
make enemies & 41.5000 & 42.581 & 0.550 & 0.838 \\
Talkative & 40.1250 & 39.855 & 0.537 & 0.838 \\
Smart & 39.3750 & 43.339 & 0.722 & 0.835 \\
Lazy & 41.0000 & 44.387 & 0.350 & 0.848 \\
Unpleasant & 40.5000 & 44.903 & 0.219 & 0.857 \\
No privacy & 39.8750 & 42.435 & 0.402 & 0.847 \\
Active & 40.0000 & 43.355 & 0.356 & 0.849 \\
Loyal & 39.5000 & 42.581 & 0.817 & 0.831 \\
Hard to be & & & & \\
found & 40.2500 & 44.581 & 0.359 & 0.847 \\
\hline
\end{tabular}

Table 6: Reliability test for turnover intention

\begin{tabular}{lllll}
\hline Item- total & $\begin{array}{l}\text { Scale mean } \\
\text { if Item } \\
\text { deleted }\end{array}$ & $\begin{array}{l}\text { variance } \\
\text { if Item } \\
\text { deleted }\end{array}$ & $\begin{array}{l}\text { Scale } \\
\text { corrected } \\
\text { item-total } \\
\text { correlation }\end{array}$ & $\begin{array}{l}\text { Cronbach's } \\
\text { alpha If } \\
\text { item deleted }\end{array}$ \\
\hline $\begin{array}{l}\text { Feel about } \\
\text { leaving this } \\
\text { organization }\end{array}$ & 5.2500 & 0.968 & 0.745 & 0.467 \\
$\begin{array}{l}\text { Your feeling } \\
\text { about your } \\
\text { future with this } \\
\text { organization }\end{array}$ & 4.3750 & 1.016 & 0.342 & 0.889 \\
$\begin{array}{l}\text { Prefer to } \\
\text { continue } \\
\text { working for this } \\
\text { organization }\end{array}$ & 5.3750 & 0.758 & 0.639 & 0.511 \\
\hline
\end{tabular}

Table 7. Correlations between study variables

\begin{tabular}{lccc}
\hline & Intrinsic & Extrinsic & $\begin{array}{c}\text { Turnover } \\
\text { intention }\end{array}$ \\
\hline Intrinsic & 1.000 & -0.000 & - \\
Extrinsic & $0.763(* *)$ & 1.000 & - \\
Turnover intention & $-0.365(*)$ & -0.172 & 1 \\
\hline ** Correlation is significant at the 0.01 level (2-tailed) * Correlation \\
is significant at the 0.05 level (2-tailed).
\end{tabular}

Table 6 indicates the Cronbach's Alpha coefficient for the turnover intention scale is 0.723 . There are total of 4 items in this scale, whereby 1 item has been omitted to increase the reliability of the measurement. Referring to the rules of thumb, the independent variable indicates that the reliability test is in 'good' range.

Pearson correlation coefficients in simple bivariate correlation were used to measure correlation between turnover intention and each variable. It shows how each of the items associated with all the other items. According to Sekaran (2003), the coefficient has a range of possible values from -1 to +1 . The value indicates the strength of the relationship, while the sign (+ or -) indicates the direction

\section{DISCUSSION}

The purposes of this study were to determine the effect of job satisfaction on turnover intentions among the employees in XYZ Sdn. Bhd, Malaysia. The statistical results obtained in this study showed that both forms of job satisfaction (intrinsic and extrinsic satisfaction) have inverse relationship on employees' turnover intentions. This result is consistent with those of previous researchers (for instance, Mobley et al., 1978; Price and Mueller, 1981; Shore and Martin, 1989; Aryee and Wyatt, 1991; Hellman, 1997; Chan and Morrison, 2000; Ghiselli et al., 2001; McBey and Karakowsky, 2001). However it is found that in this research, the intrinsic satisfaction has significantly inverse correlated with turnover intention as compared to the extrinsic satisfaction.

The small correlations existed between these study variables has been expected. During the data collection session, the employees of the company that have been servicing for more than one year have just received salary adjustment plus three months bonus. The salary adjustment and the bonuses were done to align the company's remuneration package with their merger counterpart.

When rewards received by employees are perceived as capable of fulfilling their needs and desires, they will experience a positive emotional state, which in return, induces an obligation to reciprocate their employers by being more committed. It is plausible that when employees judged the institution as being fair and supportive in their treatment particularly with regards to comfortable work conditions, relationship among the coworkers and supervisors and positive feelings of well-being will be created, which is likely to stimulate them to reciprocate by increasing their loyalty to the organization.

Likewise, when employees viewed their jobs as interesting, challenging and gratifying, providing opportunities for autonomy, self-direction and the use of multiple skills and abilities, they are likely to experience a positive emotional state, which in turn, lead them to feel committed to their jobs and organization. For this reason, their intention to leave the current institution will be reduced.

\section{CONCLUSION}

In general, this study has discussed about the relationship between job satisfaction and turnover intention in a company. The objective of the study is to examine the effects of intrinsic and extrinsic 
satisfaction on turnover intentions has been reached and completed. Statistical analysis on a sample of 32 executive and non-executive employees revealed that both components of job satisfaction had a negative impact on turnover intention.

Based on the findings, intrinsic satisfaction, however, had a stronger influence on intentions to leave in the organization. The findings have proved that there are extrinsic values that influence the turnover intention within the organization. Thus, the objective of this study was accomplished. Since extrinsic satisfaction founded to have less influence with negative relationship on turnover intention, which mean the intrinsic value were fulfilled, the turnover rate among the employees will be low compare if only extrinsic values that focused by the management to be fulfilled. It is hoped that the contributions proposed by the researchers were able to contribute towards improving human resource management at local printing company.

Recommendation: With respect to the robustness of research methodology, the data gathered from the mentoring research literature, the in-depth interviews, the pilot study and the survey questionnaires have exceeded a minimum standard of correlation and reliability analyses. This may lead to the production of accurate and reliable findings toward the company turnover intention. As the study mostly referred from Smith et al. (1969) previous study. The study still require in depth analysis as well larger number of respondents to analyze more accurate findings. More specific area as well can be carried out for the future researcher to study.

Contribution of the research: So, what can the company act to maximize it employees' job satisfaction? Based on this study here are five recommendations suggested by the researchers to be adopted in the company;

Learn about jobs that are most likely to meet employee expectations: Assist the company to identify occupations that fit employee personality and their interest. Try to get accurate information about each of them.

Do not allow employees job dissatisfactions to go unresolved for long: Job satisfactions and dissatisfactions are barometers of employees' adjustment to work. They may lead to something worse -- job loss, accidents, even mental illness. Depression, anxiety, worry, tension and interpersonal problems can result from, or be made worse by job dissatisfaction.
Overall job satisfaction is a trade-off: Educate employees and remind them that they should not expect $100 \%$ satisfaction or $0 \%$ dissatisfaction. There are usually dissatisfactions even in the best jobs. And, in today work world the employees cannot expect the employer to look out for them; they have to take the initiative yourself.

Telling the employee to look separately at the kind of work they are doing versus the conditions of work (pay, supervisor, co-workers, company and physical working conditions): If they are becoming increasingly dissatisfied with the kind of work they are doing, they should consider a career change. Where here, telling the employees to look separately at the kind of work they are doing and what they get back in return where conditions of work will not the only factors that can bring satisfactions to their job.

Encourage employees to look down the road at their possible career progress: Present dissatisfactions might be worth bearing if they see their career progressing as how good and meaningful is their current situation are presently comparing to the situation before.

Limitation of the study: The first limitation of this study relates to the sample, which were derived from a company that categorized as a small and medium industry with a small number of respondents, 32 out of 36 employees. Therefore, the findings obtained may not be generalized to other samples within the industry. Via a larger sample from other organizations in the same industry vice versa would improve the consequential of the findings.

The second limitation were the availability of data or resources-some of the relevant data to support the research may not be available due to the nature of data or information that desired to be obtained is basically not to offend the companies' confidentiality or policies that remained secretive. In this study, the company refused to expose the data regarding the staffs salaries and opportunities for promotion.

\section{REFERENCES}

Aryee, S. and T. Wyatt, 1991. Antecedents of organizational commitment and turnover intentions among professional accountants in different employment settings in Singapore. J. Soc. Psychol., 13: $545-556 . \quad$ DOI: 10.1080/00224545.1991.9713884 
Barak, M. E., J.A. Nissly and A. Levin, 2001. Antecedents to retention and turnover among child welfare, social work and other human service employees: What can we learn from past research? A review and metanalysis. Soc. Serv. Rev., 75: 625-661.

Bluedorn, A.C., 1982. A unified model of turnover from organizations. Human Relations, 35: 135-53. DOI: $10.1177 / 001872678203500204$

Buitendach, J.H. and D.D. Witte, 2005. Job insecurity, extrinsic and intrinsic job satisfaction and affective organisational commitment of maintenance workers in a parastatal. S. Afr. J. Bus. Manage., 36: 27-39.

Chan, E.Y. and P. Morrison, 2000. Factors influencing the retention and turnover intentions of registered nurses in a Singapore hospital. Nurs. Health Sci., 2: 113-121. DOI: 10.1046/j.1442-2018.2000.00046.x

Cotton, J. and J. Tuttle, 1986. Employee turnover: A meta-analysis and review with implications for research. Acad. Manage. Rev., 11: 55-70.

Dunnette, M.D. and E.A. Locke, 1976. The Nature and Causes of Job Satisfaction. Handbook of Industrial and Organizational Psychology, In Dunnette, M.D., (Ed.), 1297-1349. Rand McNally College Publishing Company Chicago, pp: 1297-1349.

Fishbein, M. and I. Ajzen, 1975. Belief, Attitude, Intention and Behavior: An Introduction to Theory and Research. Illustrated Addison-Wesley Pub. Co., ISBN-10: 0201020890, pp: 578.

Freddolino, P.P. and C.A. Heaney, 1992. Staffing issues in group homes for people labeled mentally ill: An empirical investigation of job satisfaction and intention to quit. Adult Residential Care J., 6: 115-29.

Ghiselli, R.F., J. M.L. Lopa and B. Bai, 2001. Job satisfaction, life satisfaction and turnover intent: Among food-service managers. Cornell Hotel Restaurant Admin. Q., 42: 28-37. DOI: 10.1016/S0010-8804(01)80036-7

Glick, N.L., 1992. Job satisfaction among academic administrators. Res. Higher Educ., 33: 625-639.

Hatton, C. and E. Emerson, 1998. Brief report: Organisational predictors of actual staff turnover in a service for people with multiple disabilities. J. Applied Res. Intellectual Disab., 11: 166-71. DOI: 10.1111/j.1468-3148.1998.tb00058.x

Hellman, C.M., 1997. Job satisfaction and intent to leave. J. Soc. Psychol., 137: 677-689.

Hirschfeld, R.R., 2000. Does revising the intrinsic and extrinsic subscales of the Minnesota Satisfaction Questionnaire Short Form make a difference. Educ. Psychol. Measure., 60: 255-270. DOI: 10.1177/00131640021970493
Igbaria, M., J. Iivari and H. Maragahh, 1995. Why do individuals use computer technology? A Finnish case study. Inform. Manage., 5: 227-238. DOI: 10.1016/0378-7206(95)00031-0

Kalleberg, A.L., 1977. Work values and job rewards: A theory of job satisfaction. Sociol. Q., 42: 124-143.

Kalliath, T.J. and A. Beck, 2001. Is the path to burnout and turnover paved by a lack of supervisory support? A structural equations test. New Zealand J. Psychol., 30: 72-78.

Katz, R. and J.V. Maanan, 1977. The loci of work satisfaction: Job interaction and policy. Hum. Relat., 30: 469-486. $\quad$ DOI: 10.1177/001872677703000505

Kelly, J.G. and D.G. Cross, 1985. Stress, coping behaviors and recommendations for intensive care and medical surgical ward registered nurses. Res. Nurs. Health, 8: 8-321. PMID: 3853244

Kramer, M.W., R.R. Callister and D.B. Turban, 1995. Information-receiving and information-giving during job transitions. Western J. Commu., 59: 70151.

Locke, E.A. and D. Henne, 1986. Work Motivation Theories. In: International Review of Industrial and Organizational Psychology, Cooper, C.L. and T. Robertson (Eds.)., Wiley, Chichester, pp: 1-35.

Locke, E.A., 1969. What is Job Satisfaction? Organ. Behavior Human Perfor., 4: 309-336. DOI: 10.1016/0030-5073(69)90013-0

Loscocco, K.A., 1989. The instrumentally oriented factory worker: Myth or reality? Work Occupat., 16: 3-25. DOI: 10.1177/0730888489016001001

McBey, K. and L. Karakowsky, 2001. Examining sources of influence on employee turnover in the part-time work context. Career Develop. Int., 6: 3947. DOI: 10.1108/13620430110381025

Mobley, W.H., R.W. Griffeth, H.H. Hand and B.M. Meglino, 1979. Review and conceptual analysis of the employee turnover process. Psychol. Bulletin, 86: 493-522. DOI: 10.1037/0033-2909.86.3.493

Mobley, W.H., S.O. Horner and A.T. Hollingsworth, 1978. An evaluation of precursors of hospital employee turnover. J. Appl. Psychol., 63: 408-414. PMID: 701211

Moore, K.A., 2002. Hospital restructuring: impact on nurses mediated by social support and a perception of challenge, J. Health Hum. Serv. Adm, 23: 490517. PMDI: 11924310

Mottaz, C.J., 1988. Determinants of organizational commitment. Hum. Relat., 41: 467-482. DOI: $10.1177 / 001872678804100604$ 
Muchinsky, P.M. and P.C. Morrow, 1980. A multi disciplinary model of employee turnover. J. Vocational Behav., 17: 263-290. DOI: 10.1016/0001-8791(80)90022-6

Munn, E.K. Barber and J.J. Fritz, 1996. Factors affecting the professional well-being of child life specialists. Children's Health Care, 25: 71-91. DOI: $10.1207 / \mathrm{s} 15326888 \mathrm{chc} 2502 \_1$

Nasurdin, A.M., T. Ramayah, M.A. Hemdi and S.L. Voon, 2003. Challenges of Globalized Business: The Asian Perspective, 5th Asian Academy of Management Conference, September, 2003, Kuantan, Pahang

O'Reilly, C. A. III and D.F. Caldwell, 1980. Job choice: The impact of intrinsic and extrinsic factors on subsequent satisfaction and commitment. J. Applied Psychol., 65: 559-565.

Parasuraman, S., 1982. Predicting turnover intentions and turnover behaviour: A multivariate analysis. Journal of Vocational Behavior, 21: 111-121. DOI: 10.1016/0001-8791(82)90056-2

Price, J.L. and C.W. Mueller, 1981. A causal model of turnover for nurses. Acad. Manage. J., 24: 543-565. PMID: 10252608

Rahim, M. and C. Psenicka, 1996. A structural equations model of stress, locus of control, social support, psychiatric symptoms and propensity to leave a job. J. Soc. Psychol., 136: 69-84. PMID: 8851448

Robbins, S.P., 2003. Organizational Behavior. 10th Eds., Prentice Hall, New Jersey, ISBN: 0131000691, pp: 675.

Saal, F.E. and P.A. Knight, 1995. Industrial/Organisational Psychology: Science and Practice. 2nd Edn., Brooks/Cole, California, ISBN: 0534166385, pp: 589.

Sager, J.K., 1991. The longitudinal assessment of change in sales force turnover. J. Acad. Market. Sci., 19: 25-36. DOI: 10.1007/BF02723421

Saks, A.M., 1996. The relationship between the amount of helpfulness of entry training and work outcomes. Hum. Relat., 49: 429-451. DOI: 10.1177/001872679604900402
Sekaran, U., 2003. Research Method for Business: A Skill Building Approach. 5th Edn., 1st Edn., John Wiley and Sons, New York, ISBN: 0470744790 pp: 488.

Shore, L.M. and H.J. Martin, 1989. Job Satisfaction and organizational commitment in relation to work performance and turnover intentions. Hum. Relat., 42: 625-638. DOI: 10.1177/001872678904200705

Smith, P.C., L.M. Kendall and C.L. Hulin, 1969. The Measurement of Satisfaction in Work and Retirement: A Strategy for the Study of Attitudes. 1st Edn., Rand McNally, Chicago, pp: 186.

Spector, P.E., 1997. Job Satisfaction: Application, Assessment, Causes and Consequences (Advanced Topics in Organizational Behavior). 1st Edn., Sage Publications, CA., ISBN-10: 0761989234, pp: 104.

Tan, C.G., 1998. Employee Job satisfaction and Job Turnover Intention in KL Travel Agencies,. UPM.

Tett, R.P. and J.P. Meyer, 1993. Job satisfaction, organizational commitment, turnover intention and turnover: Path analyses based on meta-analytic findings. Pers. Psychol., 46: 259-293. DOI: 10.1111/j.1744-6570.1993.tb00874.x

Thomas, K.W. and W.G. Tymon, 1994. Does empowerment always work? Understanding the role of intrinsic motivation and personal interpretation. J. Manage. Syst., 6: 1-13.

Tinker, S. and K.A. Moore, 2001. The impact of long work hours on the family-work relationship and health. Proceedings of the Inaugural Conference of APS Relationships Interest Group, Melbourne.

Vroom, V.H., 1994. Work and Motivation, 1st Edn., Wiley, New York, ISBN-10: 0787900303, pp: 397.

Williams, L.J. and J.T. Hazer, 1986. Antecedents and consequences of satisfaction and commitment in turnover models: A reanalysis using latent variable structural equation methods. J. Applied Psychol., 71: 219-231. DOI: 10.1037/0021-9010.71.2.219 